\title{
Meta-Analisis Validitas Booklet Materi Ekosistem Sebagai Suplemen Bahan Ajar Biologi Kelas X SMA
}

\author{
Rahmi', S. Syamsurizal ${ }^{*}$ \\ Universitas Negeri Padang, Padang, Indonesia \\ "Corresponding author: syam_unp@fmipa.ump.ac.id
}

\begin{abstract}
Abstrak: Penelitian ini bertujuan untuk menganalisis mengenai validitas booklet materi ekosistem sebagai suplemen bahan ajar mata pelajaran biologi kelas X SMA. Booklet sendiri adalah sebuah media pembelajaran berupa buku kecil yang memiliki paling sedikit lima halaman dan paling banyak empat puluh delapan halaman di luar hitungan sampul, kaya akan informasi penting, isinya jelas, tegas, dan mudah dimengerti. Dalam penelitian ini peneliti menggunakan metode meta analisis. Peneliti merumuskan masalah penelitian di awal, kemudian dilanjutkan dengan mencari penelitian sebelumnya yang relevan untuk dianalisis. Teknik untuk mengumpulkan data yang diperlukan dilakukan dengan teknik non tes yaitu dengan menelusuri jurnal-jurnal elektronik dan skripsi. Data yang digunakan dalam menganalisis validitas booklet sebagai bahan ajar adalah 14 artikel jurnal dan 3 skripsi. Berdasarkan hasil analisis terhadap validitas Booklet sebagai suplemen bahan ajar biologi kelas X SMA punya tingkat kevalidan dengan ratarata sebesar $91,82 \%$ dan terkategori sangat valid.
\end{abstract}

Kata Kunci: Booklet, ekosistem,suplemen bahan ajar

\begin{abstract}
This study aims to analyze the validity of the ecosystem material booklet as a supplement to teaching materials for biology class X SMA. Booklet itself is a learning media in the form of a small book that has a minimum of five pages and a maximum of eighty-eight pages including the closing count, rich in important information, the contents are clear, firm, and easy. In this study, researchers used the metaanalysis method. The researcher formulates the research problem at the beginning, then continues by looking for relevant previous research to be analyzed. The technique for collecting the required data is done by using non-test techniques, namely by tracing electronic journals and theses. The data used in analyzing the validity of booklets as teaching materials are 14 journal articles and 3 theses. Results Based on an analysis of the validity of the booklet as a supplement to biology teaching materials, class X SMA has a validity level of $91.82 \%$ on average and is categorized as very valid.
\end{abstract}

Keywords: Booklets, ecosystems, supplementary teaching materials

\section{PENDAHULUAN}

Pembelajaran berperan sangat penting dalam kehidupan manusia karena karakter yang terbentuk tergantung pada apa yang dipelajari. Pembelajaran sendiri melibatkan peserta didik dan guru yang saling berinteraksi dan berkomunikasi dengan harapan dapat mencapai tujuan pembelajaran (Afsari, 2017). Peran guru sangat berkaitan dengan proses pembelajaran sebagai bagian dari unsur pembelajaran itu sendiri yaitu sebagai pembentuk sumber daya manusia (Puspita et al., 2017). Ditengah interaksi antara guru dan peserta didik dalam proses pembelajaran melibatkan pemikiran, modul, bahan ajar, dan juga media yang menunjang berlangsungnya proses pembelajaran.

Keberhasilan dalam pembelajaran tentu sangat dipengaruhi bagaimana guru menyajikan pengetahuan melalui berbagai media (Paramita et al., 2018). Media secara harfiah berarti tengah, 
perantara, atau pengantar (Fitriani \& Krisnawati, 2019). Media pembelajaran yang baik disamping membantu guru dalam proses pembelajaran juga akan memudahkan peserta didik memahami materi. Media pembelajaran yang dirancang kreatif akan dapat dipahami dengan mudah dan cepat oleh peserta didik (Putri \& Saino, 2020).

Salah satu pembelajaran yang membutuhkan media yang dirancang secara kreatif adalah pembelajaran biologi. Berdasarkan yang kita ketahui bahwa pembelajaran biologi haruslah didasarkan pada data dan fakta ilmiah sehingga dapat dicapai pembelajaran yang bermakna (Yani, 2018). Hal ini menyebabkan banyaknya bahan ajar pembelajaran biologi hanya berisi tulisan-tulisan saja (Fitriani \& Krisnawati, 2019).

Media pembelajaran yang bisa dikreasikan dan dibuat secara kreatif salah satunya adalah booklet. Media pembelajaran berupa booklet ini bisa diterapkan di semua mata pelajaran termasuk biologi selama isi didalamnya diturunkan dari komepetensi dasar yang dibutuhkan siswa (Majid, 2011). Booklet bisa dijadikan pendamping untuk media yang sudah ada sebelumnya dalam proses pembelajaran di kelas (Jannah et al., 2020).

Booklet pada dasarnya adalah media berbasis cetak. Media berbasis cetak dapat diartikan sebagai media yang menyampaikan materi dengan dicetak secara mekanis atau dalam bentuk fotografis yang bisa berbentuk buku (Pralisaputri et al., 2016). Booklet sebagai media dapat dibuat dengan sederhana karena booklet memiliki paling sedikit lima halaman tetapi maksimalnya tidak melebihi empat puluh delapan halaman diluar hitungan sampul (Supriadie \& Darmawan, 2012). Booklet berisikan informasi-informasi penting, isinya jelas, tegas, dan harus mudah dimengerti oleh peserta didik. Booklet menjadi lebih menarik karena disajikan beserta gambar, sehingga booklet dapat dijadikan sebagai media pendamping (suplemen) untuk kegiatan pembelajaran yang diharapkan dapat meningkatkan efektivitas pembelajaran peserta didik (Intika, 2018).

Media pembelajaran booklet berbentuk cetak yang akan menyampaikan materi dalam bentuk ringkas dan gambar yang menarik sehingga memberikan kesenangan terhadap peserta didik (Wati, 2019). Ukuran booklet yang kecil menjadikannya mudah untuk dibawa kemanamana (Intika, 2018). Sifatnya sebagai media cetak menjadi kelebihan tersendiri bagi booklet. Booklet sebagai media cetak menjadikannya bisa dipelajari kapanpun karena tidak bergantung baterai handphone ataupun juga kuota internet. Booklet juga bisa dipelajari secara mandiri oleh peserta didik baik di dalam maupun di luar kelas (Putri \& Saino, 2020). Materi booklet membuat lebih banyak informasi daripada meme atau poster dan booklet yang didesain secara menarik, akan menimbulkan minat yang lebih besar pada peserta didik untuk membacanya. Kelebihankelebihan booklet ini sebagai media menjadikannya sangat cocok untuk dijadikan sebagai suplemen atau tambahan media dalam proses pembelajaran.

Pengertian suplemen itu sendiri menurut pendapat Alwi dalam Kamus Besar Bahasa Indonesia (2011: 1359) bahwa suplemen adalah sesuatu yang ditambahkan untuk melengkapi, tambahan, bagian ekstra pada surat kabar, majalah dan sebagainya, serta lampiran pelengkap. Suplemen dapat pula diartikan sebagai tambahan atau pelengkap dari sesuatu yang telah ada sebelumnya dengan maksud agar materi pembelajaran yang telah ditambahkan tersaji lebih detail.

Suplemen dapat berarti pelengkap, penunjang atau tambahan, sedangkan pembelajaran ialah proses belajar mengajar untuk memperoleh ilmu sehingga dapat menyebabkan perubahan tingkah laku individu. Suplemen pembelajaran dapat didefinisikan sebagai alat tambahan yang dapat melengkapi proses pembelajaran di kelas. Proses pembelajaran di sekolah biasanya mengunakan buku teks. Adanya keterbatasan pada buku teks yang digunakan di sekolah menjadi alasan perlu dikembangkannya buku suplemen atau buku penunjang yang dapat melengkapi pemahaman siswa terhadap materi pembelajaran (Kurniasari et al., 2014).

Berdasarkan hasil observasi dan wawancara dengan ibu Dasmawati S.Pd sebagai seorang guru biologi di SMA Negeri 1 Matur, diperoleh informasi bahwa materi ekosistem sebagai salah satu materi pelajaran biologi yang diajarkan untuk peserta didik kelas $\mathrm{X}$ di semester genap adalah materi yang sulit dipahami. Mungkin sebagian orang menganggap mudah materi ekosistem, tapi dari yang dipaparkan oleh ibu Dasmawati, 50\% dari peserta didik kelas $X$ masih memperoleh 
nilai dibawah ketuntasan minimum untuk materi ekosistem. Sulitnya peserta didik memahami materi tersebut karena materi yang bersifat hafalan dan banyak istilah yang tidak dipahami oleh peserta didik.

Ditambah dengan media pembelajaran utama yang biasanya digunakan berupa LKPD yang memuat lebih banyak soal daripada konsep. Walaupun untuk beberapa kesempatan ada digunakan buku teks pelajaran, tapi buku teks yang tebal dan berat serta lebih didominasi tulisan membuat peserta didik cenderung tidak suka membaca buku teks tersebut.

Hasil angket observasi yang diisi oleh peserta didik yang sudah pernah belajar materi ekosistem sebelumnya, menunjukkan bahwa 65,7 \% siswa menyatakan sulit memahami materi ekosistem. Menurut peserta didik kesulitan yang mereka rasakan karena terlalu banyaknya materi pembelajaran. Observasi yang dilakukan di SMA N 1 Matur juga mendapatkan hasil bahwa $88,6 \%$ peserta didik menyatakan bahwa mereka membutuhkan sumber belajar lain yang menunjang pemahaman mereka terkait materi ekosistem. $80 \%$ dari peserta didik menginginkan sumber belajar yang dapat dipahami secara mandiri. Kriteria sumber belajar yang menarik bagi peserta didik adalah yang menyampaiakan materi secara lengkap, singkat, padat dan jelas; menggunakan bahasa yang mudah dipahami, memuat penjelas untuk istilah sulit, disertai gambar, dan berwarna di setiap halaman.

Sebanyak $88,6 \%$ peserta didik setuju jika dikembangkan materi pembelajaran ekosistem dalam bentuk Booklet. Guru biologi SMA N 1 Matur, yaitu ibuk Dasmawati, S.Pd juga setuju jika dikembangkannya bahan ajar berupa Booklet pada materi ekosistem. Menurut ibuk Dasmawati, S.Pd media pembelajaran yang disukai peserta didik adalah yang memilki materi yang lengkap, singkat, padat, dan jelas. Sementara itu selama ini guru masih cenderung menggunakan LKPD, buku paket dan modul dalam proses pembelajaran dan membutuhkan sumber belajar lain untuk materi ekosistem sebagai tambahan bahan ajar.

Diperkuat oleh penelitian yang dilakukan sebelumnya oleh Imtihana (2014), didapatkan hasil bahwa booklet dapat meningkatkan motivasi dan gairah peserta didik dalam belajar karena pada dasarnya peserta didik sangat tertarik dengan hal baru. Hal ini ditunjukkan dengan 100\% peserta didik menyatakan bahwa booklet memilki isi yang menarik. Media Booklet yang dikembangkan juga sangat valid dan praktis, bahkan efektif dalam meningkatkan hasil belajar siswa sebesar $>80 \%$ (Imtihana et al., 2014).

Berdasarkan observasi tersebut, disimpulkan bahwa peserta didik membutuhkan tambahan bahan ajar untuk mendampingi bahan ajar yang sudah ada. Pemaparan diatas membuat penulis melakukan penelitian validitas booklet materi ekosistem sebagai suplemen bahan ajar biologi.

\section{METODE PENELITIAN}

Jenis penelitian yang digunakan pada penelitian ini adalah meta-analisis. Meta analisis adalah jenis penelitian yang dilakukan dengan cara mengumpulkan data penelitian, kemudian dilakukan review dan selanjutnya data-data penelitian yang didapat dari penelitian yang sudah dilakukan sebelumnya dianalisis. Pengumpulan data penelitian dilakukan dengan cara menelusuri artikel-artikel yang terdapat pada jurnal online dan juga skripsi. Pada saat mencari jurnal online pada, ada beberapa kata kunci yang dimasukkan pada jendela pencarian yaitu "Booklet, validitas". Dengan keywords tersebut didapatkan banyak sekali artikel jurnal maupun skripsi, namun akan diseleksi kembali manakah artikel jurnal dan skripsi yang sesuai kriteria. Penyeleksian artikel jurnal dan yang sesuai dengan tujuan penelitian yaitu "Validitas booklet ekosistem sebagai suplemen bahan ajar biologi kelas X SMA" dilakukan dengan melihat kesesuaian judul dan dan hasil validitas bahan ajar dengan tujuan penelitian. Artikel jurnal dan skripsi yang dikumpulkan adalah yang terbit diatas tahun 2016 yang tergolong masih baru. Data dikumpulkan dan dilakukan analisis dengan menggunakan metode deskriptif, yaitu dengan menganalisis data validitas bahan ajar booklet yang sudah ada. Data validitasnya melingkupi validitas aspek isi, bahasa, penyajiaan, dan kegrafikaan untuk masing-masing bahan ajar booklet. Data validitas 
tersebut kemudian dicari rata-ratanya untuk mendapatkan nilai presentasi dari validitas booklet secara keseluruhan. Rata-rata akhir validitas dihitung menggunakan rumus berikut:

Keterangan:

$$
\text { Persentase }=\frac{X}{Y}
$$

$X=$ Jumlah persentase yang diperoleh

$\mathrm{Y}=$ Banyak data

Dengan kriteria penilaian validitas sebagai berikut:

\begin{tabular}{cc}
\multicolumn{2}{c}{ Tabel 1. Kategori kevalidan suatu produk } \\
\hline Persentase (\%) & Kriteria kevalidan \\
\hline $81 \%-100 \%$ & Sangat valid \\
$61 \%-80 \%$ & Valid \\
$41 \%-60 \%$ & Tidak valid \\
$\geq 21 \%-40 \%$ & Sangat tidak valid \\
\hline & (Arikunto, 2010:3!
\end{tabular}

\section{HASIL DAN PEMBAHASAN}

Hasil penelitian diperoleh artikel dan skripsi yang terkait dengan validitas booklet sebagai bahan ajar. Data hasil penelitian diolah dengan cara dirangkum dan ditentukan intisari hasil penelitian dari pengembangan booklet sebagai bahan ajar. Kemudian data dilaporkan kembali dengan cara deskriptif kualitatif dan kuantitatif. Data hasil analisis pengembangan booklet sebagai bhan ajar dari jurnal dan skripsi disajikan pada Tabel 2.

Tabel 2. Persentase Nilai Validitas Booklet Sebagai Bahan Ajar dari Beberapa Penelitian

\begin{tabular}{clcccc}
\hline \multirow{2}{*}{ No } & \multirow{2}{*}{ Peneliti } & \multicolumn{3}{c}{ Aspek Yang Divalidasi } \\
\cline { 2 - 5 } & Isi (\%) & Bahasa(\%) & Penyajian (\%) & Kegrafikaan (\%) \\
\hline 1. & Alencia (2021) & 95,30 & 91,60 & 87,50 & 95,00 \\
2. & Apriyeni, et al. (2021) & 84,25 & 88,33 & 86,11 & 87,50 \\
3. & Gusti \& Syamsurizal (2021) & 89,28 & 90,00 & 89,81 & 86,66 \\
4. & Harahap, et al. (2020) & 91,25 & 88,00 & 84,00 & 95,00 \\
5. & Ikhtiarni, et al. (2021) & 92,05 & 92,16 & 93,33 & 95,83 \\
6. & Jannah, et al. (2020) & 96,52 & 96,52 & 96,52 & 83,75 \\
7. & Liumah (2017) & 99,17 & 86,46 & 97,22 & 100,00 \\
8. & Masrifah, et al. (2020) & 90,00 & 88,09 & 95,83 & 86,67 \\
9. & Muhammad, et al. (2018) & 90,00 & 86,50 & 82,50 & 85,00 \\
10. & Nisa, et al. (2021) & 90,00 & 80,00 & 80,00 & 80,00 \\
11. & Octiana, et al. (2020) & 95,00 & 92,85 & 93,05 & 91,67 \\
12. & Putri \& Saino (2020) & 86,00 & 80,00 & 86,00 & 79,00 \\
13. & Putri (2021) & 90,47 & 85,00 & 88,33 & 86,90 \\
14. & Sholehah, et al. (2017) & 87,50 & 66,70 & 93,80 & 93,30 \\
15. & Wati (2019) & 90,60 & 95,50 & 88,30 & 90,80 \\
16. & Wulandari, et al. (2018) & 100,00 & 90,60 & 95,80 & 98,50 \\
17. & Zuyina \& Widodo (2020) & 98,00 & 91,00 & 92,00 & 96,00 \\
\hline
\end{tabular}

Tabel 3. Hasil Analisis Uji Validitas Booklet Sebagai Bahan Ajar

\begin{tabular}{clcl}
\hline No & Komponen & Nilai Validitas $(\%)$ & Kriteria \\
\hline 1. & Isi & 92,08 & Sangat Valid \\
2. & Bahasa & 87,60 & Sangat Valid \\
3. & Penyajian & 90,00 & Sangat Valid \\
4. & Kegrafikaan & 90,09 & Sangat Valid \\
\hline & Rata-rata & 89,94 & Sangat Valid \\
\hline
\end{tabular}


Berdasarkan hasil rata-rata akhir dari nilai validitas bahan ajar booklet yang terdapat pada Tabel 3 yaitu 89,94\% termasuk dalam kriteria sangat valid menurut Arikunto (2010). Hasil ratarata ini sebanding dengan nilai dari semua aspeknya yang juga sangat valid baik dari segi isi, bahasa, penyajian, maupun kegrafikaan. Nilai validitas aspek kelayakan isi sebesar 92,08\%, kelayakan bahasa 87,60 \%, kelayakan penyajian 90,00\%, dan kelayakan kegrafikaan 89,94\%.

Kelayakan isi bahan ajar booklet yang sangat valid menunjukkan bahwa bahan ajar booklet telah sesuai dengan kurikulum, Kompetensi inti (KI), Kompetensi dasar (KD), Indikator Pencapaian Kompetensi, serta tujuan dari pembelajaran yang ingin dicapai. Sesuai dengan kriteria kelayakan isi menurut Depdiknas (2008). Kriteria sangat valid juga menunjukkan bahwa materi yang ada dalam bahan ajar booklet sudah benar dan tidak bertentangan dengan nilai moral dan sosial. Ditambah, kriteria sangat valid ini menunjukkan bahwa isi dari booklet telah sesuai dengan tingkat berpikir peserta didik serta dapat membantu peserta didik dan guru dalam proses pembelajaran (Apriyeni, et al., 2021).

Aspek kelayakan bahasa juga sangat valid berarti susunan kalimat yang digunakan dalam bahan ajar booklet jelas, penggunaan kalimat tidak menimbulkan penafsiran ganda dan salah pengertian, penggunaan bahasa sesuai dengan kaidah EYD (Pramita, et al., 2018). Pemilihan istilah dan kata yang tepat serta bahasa yang tidak berbelit-belit juga menjadi hal yang sangat bagus dalam pembuatan media pembelajaran (Fitriani \& Krisnawati, 2019).

Tersusunnya materi dengan baik dan sistematis menjadi salah satu kriteria dari kelayakan penyajian yang sangat valid. Booklet juga memberikan motivasi belajar pada peserta didik, interaktif, dan menampilkan informasi yang lengkap serta jelas, hal ini sesuai dengan kriteria Depdiknas (2008). Tersusunnya materi pembelajaran secara sistematis akan membuat peserta didik senang dan mudah dalam proses pembelajaran (Apriyeni, et al., 2021).

Aspek kegrafikaan adalah aspek penampilan dari bahan ajar itu sendiri. Aspek kegrafikaan yang sangat valid berarti tampilan fisik mulai dari cover, pemilihan warna, jenis tulisan maupun ukuran tulisan booklet sudah sangat baik. Resolusi gambar dan keakuratan warna serta jenis kertas juga akan memengaruhi bahan ajar dalam bentuk cetak (Fitriani \& Krisnawati, 2019: 149). Aspek kegrafikaan juga bisa dinilai dari tata letak komponen dan pemilihan gambar yang sesuai, daya tarik, spasi yang kosong pada booklet (Putri \& Saino, 2020).

Secara keseluruhan artikel dan skripsi bahan ajar booklet yang dianalisis sudah sangat valid dengan nilai di setiap kriteria validitas yang tinggi. Bahan ajar booklet yang sangat valid sudah bisa digunakan dan diuji coba di lapangan. Bagi peneliti sendiri menjadi gambaran dan rujukan untuk dapat terpenuhinya validitas booklet ekosistem sebagai suplemen bahan ajar untuk peserta didik kelas X SMA dengan kriteria sangat valid.

\section{KESIMPULAN}

Hasil meta analisis dari validitas booklet sebagai suplemen bahan ajar terhadap 17 artikel dan skripsi yang peneliti lakukan sangat valid dengan nilai $89,94 \%$. Disimpulkan bahwa validitas booklet ekosistem sebagai suplemen bahan ajar untuk peserta didik kelas X SMA memperoleh gambaran dan harapan terpenuhinya kategori sangat valid serta bisa dilanjutakan ke tahapan uji respon di lapangan.

\section{UCAPAN TERIMA KASIH}

Peneliti mengucapkan syukur kepada Allah, Tuhan Yang Maha Baik, terima ksih kepada orangtua, dosen pembimbing, dosen-dosen yang sudah membantu, dan teman-teman yang selalu mendukung dalam penyelesaian artikel sampai artikel ini publish.

\section{DAFTAR PUSTAKA}

Afsari. (2017). Pengembangan Lembar Kerja Peserta Didik (Lkpd) Berpikir Tingkat Tinggi Pada Pokok Bahasan Sel Kelas Xi Ipa Sma Negeri 16 Makassar. Skripsi. Makassar: Universitas Islam Negeri (Uin) Alauddin Makassar.

Alencia, P. 2021. Pengembangan Booklet Klasifikasi Makhluk Hidup Sebagai Suplemen Bahan Ajar IPA Kelas VII SMP. Skripsi. Padang: Universitas Negeri Padang. 
Alwi, H. (2011). Kamus Besar Bahasa Indonesia. Jakarta: Pustaka Utama.

Apriyeni, O., Syamsurizal, Alberida, H., Rahmi, Y. (2021). Booklet Pada Materi Bakteri Untuk Peserta Didik Kelas X SMA. Jurnal Edutech Undiksha, 8(1), 8-13.

Arikunto, S., \& Jabar, C. (2010). Evaluasi Dalam Program Pendidikan: Pedoman Teoritis Praktis Bagi Mahasiswa Dan Praktisi Pendidikan. Jakarta: Bumi Aksara.

Depdiknas. (2008). Panduan Pengembangan Bahan Ajar. Jakarta: Depdiknas.

Fitriani \& Krisnawati, L., \& Krisnawati, Y. (2019). Pengembangan Media Booklet Berbasis Keanekaragaman Jenis Jamur Makroskopis. Biodesains, 2(2), 143-151.

Gusti, U., \& Syamsurizal, S. (2021). Uji Validitas Booklet Struktur Dan Fungsi Jaringan Tumbuhan Untuk Peserta Didik Kelas XI SMA/MA. Bioedusiana: Jurnal Pendidikan Biologi, 6 (1), 70-78.

Harahap, I., Helendra, Farma, S., \& Syamsurizal. (2020). Validitas Booklet Sistem Pernapasan Manusia sebagai Suplemen Bahan Ajar IPA. Bioeducation Journal, 4(2), 104-112.

Ikhtiarni, F., Ardi., \& Darussyamsu, R. (2021). Validity Of ESQ Booklet About Structure And Function Of Animal Tissue As Biology Learning Supplement. Edubiotik: Jurnal Pendidikan, Biologi dan Terapan, 6(1), 26-39.

Imtihana, M., Martin, F. P., B, H., \& Priyono, B. (2014). Pengembangan Buklet Berbasis Penelitian Sebagai Sumber Belajar Materi Pencemaran Lingkungan Di SMA. Unnes Journal Of Biology Education, 3(2), 186-192.

Intika, T. (2018). Pengembangan Media Booklet Science For Kids Sebagai Sumber Belajar Di Sekolah Dasar . Jurna Riset Pendidikan Dasar, 1(1), 10-17.

Jannah, U., Widiyaningrum, P., \& Saptono, S. (2020). Pengembangan Buklet Karakter Peduli Lingkungan Sub Materi Komponen Ekosistem Di SMA. Jurnal Bioma, 9(1), 13-28.

Kurniasari, D., Rusilowati, A., dan Subekti, N. 2014. Pengembangan Buku Suplemen IPA Terpadu dengan Tema Pendengaran Kelas VIII. Unnes Science Education Journal, 3 (2), 463.

Liumah, Muhidatul. 2017. Pengembangan Booklet Edukasi Berbasis Pengetahuan Dan Sikap Sadar Sehat Reproduksi Di Pondok Pesantren Mamba'ul Hisan Isyhar Nganjuk. Jurnal Simki, ISSN: 2599-0756, 3-13

Majid A. (2011). Perencanaan Pembelajaran: Mengembangkan Standar Kompetensi Guru. Bandug: Rosda.

Masrifah, S., Musdansi, D., \& Rahayuningsih,J. (2020). Pengembangan Media Pembelajaran Booklet Pada Materi Sistem Koloid Untuk Kelas XI IPA (SMA Negeri 1 Benai). JOM FTK UNIKS, 2 (1), 159-166.

Muhammad, F., P., M., \& Adnan. (2018). Pembelajaran Arthropoda Menggunakan Booklet sebagai Sumber Belajar Mandiri Siswa Kelas X SMA/MA. Jurnal Biology Teaching and Learning, 1(1), 28-32.

Nisa, K., Ajizah, A., \& Amintarti, S. 2021. The Validity Of Learning Media In the Form Of Booklet Types Of Pteridophyta (Fern) In The Riverbanks Of Wisata Alam Sungai Kembang For Senior High School Grade X. Bio-Inoved: Jurnal Biologi-Inovasi Pendidikan, 3(2), 92-97.

Octiana, N., Darussyamsu, R., Yogica, R., \& Syamsurizal. (2020). Validitas Booklet pada Materi Pola Pewarisan Sifat pada Hukum Mendel sebagai Suplemen Pembelajaran Genetika di SMA. Jurnal Pendidikan Biologi, 5(3), 2656-1700.

Paramita, R., Panjaitan, R., \& Ariyati, E. (2018). Pengembangan Booklet Hasil Inventarisasi Tumbuhan Obat Sebagai Media Pembelajaran Pada Materi Manfaat Keanekaragaman Hayati. (JIPI) Jurnal IPA dan Pembelajaran IPA, 2(2), 83-88.

Pralisaputri, K., Heribertus, S., \& Chatarina, M. (2016). Pengembangan Media Booklet Berbasis SETS Pada Materi Pokok Mitigasi Dan Adaptasi Bencana Alam Untuk Kelas X SMA. Jurnal GeoEco, 2(2), 147-154.

Puspita, A., Kurniawan, A., \& Rahayu,H. (2017). Pengembangan Media Pembelajaran Booklet Pada Materi Sistem Imun Terhadap Hasil Belajar Siswa Kelas XI SMAN 8 Pontianak. Jurnal Bioeducation, 4(1), 64-73.

Putri, N. 2021. Pengembangan Booklet Sistem Ekskresi Manusia Sebagai Suplemen Bahan Ajar Biologi Kelas XI SMA/MA. Skripsi. Padang: Universitas Negeri Padang. 
Putri, N., \& Saino. (2020). Pengembangan Booklet Sebagai Media Pembelajaran Pada Mata Pelajaran Pengelolaan Bisnis Ritel Materi Perlindungan Konsumen Kelas XI BDP Di SMKN Mojoagung. Jurnal Pendidikan Tata Niaga, 8(3), 925-931.

Sholehah, N., Irawati, M., \& Sueb. (2017). Pengembangan Booklet Kawasan Rumah Pangan Lestari (KRPL) Untuk Santri Ekopesantren Lombok Tengah. Jurnal Pendidikan: Teori, Penelitian, Dan Pengembangan, 2(8), 1081-1086.

Supriadie, D., \& Darmawan, D. (2012). Komunikasi Pembelajaran. Bandung: Remaja Rosdakarya.

Wati, Tyas saras. (2019). Pengembangan Booklet Edukasi Kesehatan Reproduksi Terintegrasi Nilai Islam Sebagai Sumber Belajar Kesehatan Reproduksi Pada Santri Putri \& Saino Di Pondok Pesantren Al Munawwir Batang. Skripsi. Semarang: Universitas Islam Negeri Walisongo Semarang

Wulandari, N., Irawati, M., \& Nugrahaningsih. (2018). Developing an Organic Liquid Fertilizer Booklet To Support The Sustainable Reserve Food Garden (SRFG) Program At Tunggak Cerme, Wonomerto, Probolinggo. Indonesian Journal Of Biology And Education, 1 (1), 31 34.

Yani, A., Muhsyanu., Sahriah., Haerunnisa., \& Salmawati, S. 2018. Efektivitas Pendekatan Saintifik Dengan Media Booklet Higher Order Thinking Terhadap Hasil Belajar Biologi. Jurnal Biology Science \& Education, 7(1), 1-12.

Zuyina, A., \& Widodo, W. (2020). Validity Of Ethnoscience Booklet Media In The Region Of Ponorogo On Sound Wave Sub Material. Pensa E-Jurnal: Pendidikan Sains, 8(2), 178-182. 